JOURNAL OF

APPLIED

CRYSTALLOGRAPHY

ISSN 1600-5767

Received 17 May 2021

Accepted 17 September 2021

Edited by H. Brand, Australian Synchrotron, ANSTO, Australia

Keywords: agrinierite; rameauite; twinning; merohedry; Jana2020.

CCDC references: 2110502; 2115477

Supporting information: this article has supporting information at journals.iucr.org/j

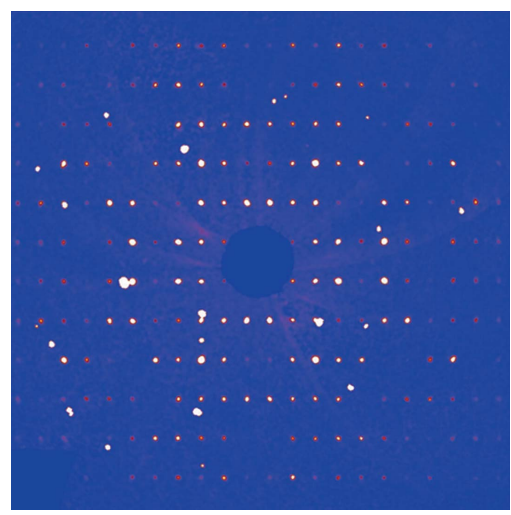

\section{Hidden and apparent twins in uranyl-oxide minerals agrinierite and rameauite: a demonstration of metric and reticular merohedry}

\author{
Jakub Plášil, ${ }^{\mathrm{a} *}$ Václav Petříček, ${ }^{\mathrm{a}}$ Radek Škoda, ${ }^{\mathrm{b}}$ Nicolas Meisser ${ }^{\mathrm{c}}$ and \\ Anatoly V. Kasatkin ${ }^{\text {d }}$
}

\begin{abstract}
anstitute of Physics ASCR, v.v.i., Na Slovance 2, Prague 8, 18221, Czech Republic, ${ }^{\mathbf{b}}$ Department of Geological Sciences, Masaryk University, Kotlářská 2, Brno, 61137, Czech Republic, '⿳M ' Musée cantonal de géologie, Université de Lausanne, Anthropole, Dorigny CH-1015, Switzerland, and ${ }^{\mathbf{d}}$ Fersman Mineralogical Museum of the Russian Academy of Sciences, Leninsky Prospekt 18-2, Moscow 119071, Russian Federation. *Correspondence e-mail: plasil@fzu.cz
\end{abstract}

In this work, the structures of chemically related uranyl-oxide minerals agrinierite and rameauite have been revisited and some corrections to the available structure data are provided. Both structures were found to be twinned. The two minerals are chemically similar, and though their structures differ considerably, their unit-cell metrics are similar. Agrinierite was found to be twinned by metric merohedry (diffraction type I), whereas the structure of rameauite is twinned by reticular merohedry (diffraction type II). The twinning of the monoclinic unit cells (true cells) leads to pseudo-orthorhombic or pseudotetragonal supercells in the single-crystal diffraction patterns of both minerals. According to the new data and refinement, agrinierite is monoclinic (space group $C m$ ), with $a=14.069$ (3), $b=14.220$ (3), $c=13.967$ (3) $\AA$, $\beta=120.24$ (12) ${ }^{\circ}$ and $V=2414.2(12) \AA^{3}(Z=2)$. The twinning can be expressed as a mirror in (101) (apart from the inversion twin), which leads to a supercell with $a=14.121$, $b=14.276, c=24.221 \AA$ and $V=2 \times 2441 \AA^{3}$, which is $F$ centered. The new structure refinement converged to $R=3.54 \%$ for 6545 unique observed reflections with $I>3 \sigma(I)$ and GOF $=1.07$. Rameauite is also monoclinic (space group $C c$ ), with $a=13.947$ (3), $b=14.300$ (3), $c=13.888$ (3) $\AA, \beta=118.50$ (3) and $V=2434.3(11) \AA^{3}(Z=2)$. The twinning can be expressed as a mirror in (101) (apart from the inversion twin), which leads to a supercell with $a=14.223$, $b=14.300, c=23.921 \AA$ and $V=2 \times 2434 \AA^{3}$, which is $C$ centered. The new structure refinement of rameauite converged to $R=4.23 \%$ for 2344 unique observed reflections with $I>3 \sigma(I)$ and GOF $=1.48$. The current investigation documented how peculiar twinning can be, not only for this group of minerals, and how care must be taken in handling the data biased by twinning.

\section{Introduction}

Uranyl-oxide hydroxy-hydrates (UOHs) represent a fascinating group of minerals and synthetic phases, closely connected with the hydration-oxidation of uranium dioxide, $\mathrm{UO}_{2+x}$, as nuclear fuel or uraninite (Finch \& Ewing, 1992; Wronkiewicz et al., 1996; Janeczek et al. 1996; Plášil, 2014, 2018a). They occur in nature as minerals and are among the first alteration products that form during weathering of uraninite (pitchblende) in oxidized zones of $\mathrm{U}$ deposits worldwide (Finch, Suksi et al., 1996; Finch, Cooper et al., 1996; Plášil, 2018a). Numerous studies focused on their structures, solubilities and thermodynamic stabilities were undertaken in the 1990s and at the beginning of the millennium (e.g. Casas et al., 1997; Finch \& Murakami, 1999; Kubatko et al. 2006; Klingensmith et al., 2007; Gorman-Lewis et al., 2008) due to the general importance of UOHs in nuclear waste disposal and the environmental chemistry of uranium. Nevertheless, the 
results of recent scientific efforts have proven even greater complexity and variability of the entire group (Kirkegaard $e t$ al., 2019; Lu, Zhang, Wei et al., 2020; Lu, Zhang, Aughterson \& Zheng, 2020; Olds et al., 2017, 2018; Plášil, 2017, 2018b; Plášil et al., 2018, 2020; Zhang et al., 2016, 2018, 2019).

Agrinierite and rameauite are interesting $\mathrm{UOHs}$, having the same type locality, the Margnac mine (Compreignac, HauteVienne, Nouvelle-Aquitaine) in France (Cesbron et al., 1972). Agrinierite, $\mathrm{K}_{2}\left(\mathrm{Ca}_{0.65} \mathrm{Sr}_{0.35}\right)\left[\left(\mathrm{UO}_{2}\right)_{3} \mathrm{O}_{3}(\mathrm{OH})_{2}\right]_{2} \cdot 5 \mathrm{H}_{2} \mathrm{O}$ (Cahill \& Burns, 2000), has been so far the only naturally occurring $\mathrm{UOH}$ to contain an essential amount of $\mathrm{Sr}$, reported by Cesbron et al. (1972). This is of interest due to the possible incorporation of ${ }^{90} \mathrm{Sr}$ into the alteration phases of spent nuclear fuel. The rameauite structure has been revealed relatively recently by Plášil et al. (2016). The ideal chemical formula of rameauite is $\mathrm{K}_{2} \mathrm{Ca}\left[\left(\mathrm{UO}_{2}\right)_{3} \mathrm{O}_{3}(\mathrm{OH})_{2}\right]_{2} \cdot 6 \mathrm{H}_{2} \mathrm{O}$.

According to the structure studies by Cahill \& Burns (2000), agrinierite is orthorhombic (space group $F 2 \mathrm{~mm}, Z=16$ ) with $a=14.094$ (2), $b=14.127$ (2), $c=24.106$ (4) $\AA$ and $V=$ 4799.6 (1) $\AA^{3}$. Rameauite is reported (Plášil et al., 2016) to be monoclinic (space group $C c, Z=4$ ) with $a=13.9458(19), b=$ 14.3105 (19), $c=13.8959$ (18) $\AA, \beta=118.477(14)^{\circ}$ and $V=$ 2437.7 (6) $\AA^{3}$. The unit-cell volume of rameauite is approximately half that of agrinierite. The structure of agrinierite has been refined to $R=6.55 \%$ for 2710 unique observed reflections with $I>4 \sigma(I)$ and GOF $=0.851$ [SHELXTL (Sheldrick, 2008) software used]. The rameauite structure has been refined to $R=6.00 \%$ for 1696 unique observed reflections with $I>3 \sigma(I)$ and GOF $=1.62$ [Jana2006 (Petříček et al., 2014) software used].

While the $\mathrm{UOH}$ sheets in the structure of agrinierite are based on the $\alpha-\mathrm{U}_{3} \mathrm{O}_{8}$ type, the sheets in rameauite, despite the overall chemical similarity, are based upon the $\beta-\mathrm{U}_{3} \mathrm{O}_{8}$ type (Fig. 1)

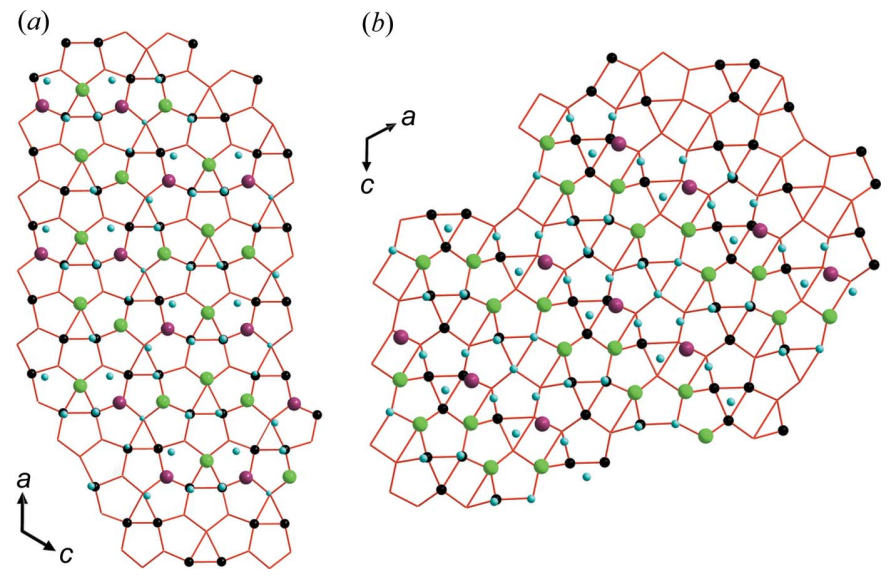

Figure 1

Topology of the UOH layers (red lines) and the distribution of interlayer constituents in $(a)$ agrinierite and $(b)$ rameauite. The agrinierite $\mathrm{UOH}$ sheet is based on the $\alpha-\mathrm{U}_{3} \mathrm{O}_{8}$ type with rods of pentagons and rods of pentagons linked with triangles (oriented up and down). The sheet in rameauite is based on the $\beta$ - $\mathrm{U}_{3} \mathrm{O}_{8}$ type with rods of pentagons linked with triangles (oriented up and down) and rectangles. Color scheme: $\mathrm{Ca} / \mathrm{Sr}$ sites are pink, $\mathrm{K}$ sites are green, blue spheres are $\mathrm{O}$ of molecular $\mathrm{H}_{2} \mathrm{O}$, black dots within the sheets are $\mathrm{OH}$ groups.
The close chemical and structural similarities of the two UOHs prompted us to reinvestigate their structures. This revision led us to the conclusion that both structures are affected by twinning. Here we report the investigation of twinning in both minerals and provide a correct description of the agrinierite unit cell and improved structure models.

\section{Methodology}

\subsection{Samples studied}

The studied specimen of agrinierite originates from the type locality: the former Margnac $\mathrm{U}$ mine located about $3 \mathrm{~km}$ from Compreignac, Haute-Vienne, Nouvelle-Aquitaine, France (Cesbron et al. 1972). The studied sample $(8 \times 4 \times 3 \mathrm{~mm})$ is constituted of earthy and massive yellow or orange 'gummite' crosscut by inframillimetre-sized veins covered with well shaped orange UOHs, including agrinierite and acicular uranophane- $\alpha$ crystals. In these veins, agrinierite occurs as small (up to $0.8 \mathrm{~mm}$ long) pumpkin-orange tabular crystals on $\{001\}$ pseudo-hexagonal crystals. The sample is preserved in the collection of the Geological Museum of Lausanne, Switzerland (catalog No. MGL 093238). From the same centimetre-sized mineral association, other $\mathrm{UOH}$ minerals analyzed utilizing powder X-ray diffraction and energydispersive X-ray spectroscopy reflect the distribution of alkaline and alkaline-earth elements on a millimetre scale: compreignacite $(\mathrm{K})$, becquerelite $(\mathrm{Ca})$ and billietite $(\mathrm{Ba})$ (samples MGL 094375-094378).

Rameauite has been studied by Plášil et al. (2016) using the specimen originating from Margnac, France.

\subsection{Chemical composition of agrinierite}

Even though agrinierite was discovered and described $c a 50$ years ago (Cesbron et al., 1972), its chemical composition remains poorly studied. In the original description, Cesbron et al. (1972) provided only one wet-chemical analysis and, for instance, reported a $2.05 \mathrm{wt} \%$ of $\mathrm{SrO}[\sim 0.40 \mathrm{Sr}$ atoms per formula unit (apfu)]. Cahill \& Burns (2000) did not provide any chemical data and only gave the composition from the refined structure. The official International Mineralogical Association list of minerals reports agrinierite as $\mathrm{K}_{2} \mathrm{Ca}\left[\left(\mathrm{UO}_{2}\right)_{3} \mathrm{O}_{3}(\mathrm{OH})_{2}\right]_{2} \cdot 5 \mathrm{H}_{2} \mathrm{O}$, thus totally neglecting the $\mathrm{Sr}$ content in the mineral. In response, we decided to undertake new reliable quantitative chemistry determination by electron microprobe. Crystals of agrinierite were mounted on epoxy resin, polished and carbon-coated to determine their chemical compositions utilizing a CAMECA SX100 electron microprobe. The measurement was performed in wavelengthdispersive mode at $15 \mathrm{kV}$ accelerating voltage, $2 \mathrm{nA}$ beam current and $15 \mu \mathrm{m}$ beam diameter using the following standards: synthetic $\mathrm{UO}_{2}$ for $\mathrm{U}$, synthetic $\mathrm{SrSO}_{4}$ for $\mathrm{Sr}$, wollastonite for $\mathrm{Ca}$ and sanidine for $\mathrm{K}$. No other elements were above the detection limit. Regardless of the mild analytical conditions, a systematic decrease of $\mathrm{K} K \alpha \mathrm{X}$-ray intensity during the analysis was observed. Thus, $\mathrm{K}$ was analyzed at the beginning of each measurement; the integration time of $\mathrm{K}$ was divided 
Table 1

Details for the data collection and refinement for agrinierite and rameauite.

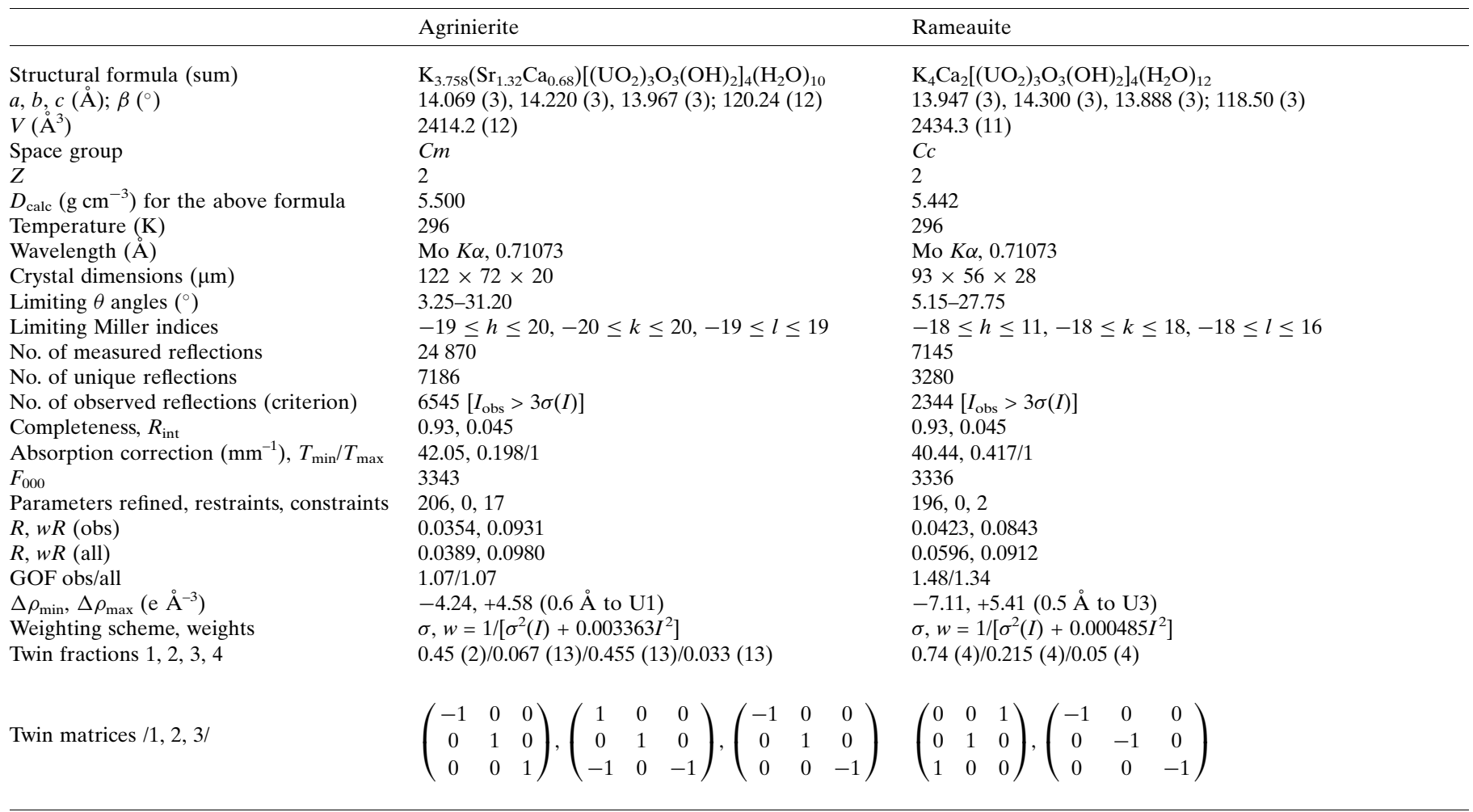

into four periods and the concentration was calculated from the values of $\mathrm{K} K \alpha$ intensities extrapolated to time zero. The raw intensities were processed for matrix corrections using $X$-PHI matrix corrections (Merlet, 1994) involving a stoichiometric amount of $\mathrm{H}_{2} \mathrm{O}$. The empirical formula was calculated on the basis of $6 \mathrm{U}$ and the amounts of $\mathrm{O}, \mathrm{OH}$ and $\mathrm{H}_{2} \mathrm{O}$ were derived from the structure and the rule of electroneutrality. Atomic proportions are shown in apfu (atoms per formula unit).

The agrinierite studied is chemically heterogeneous, particularly in the $\mathrm{Ca}(0.30-0.61 \mathrm{apfu} ; 0.83-1.69 \mathrm{wt} \% \mathrm{CaO})$ and $\mathrm{Sr}$ (0.48-0.67 apfu; 2.49-3.50 wt \% SrO) contents. The K content is $1.23-1.38$ apfu $\left(2.87-3.23 \mathrm{wt} \% \quad \mathrm{~K}_{2} \mathrm{O}\right)$. Considering the average amounts of $\mathrm{UO}_{3}(85.62 \mathrm{wt} \%)$ and $\mathrm{H}_{2} \mathrm{O}(6.29 \mathrm{wt} \%)$, the average analytical sum is $99.16 \mathrm{wt} \%$. The mean $(n=10)$ empirical formula of agrinierite is $\mathrm{K}_{1.31}\left(\mathrm{Sr}_{0.56} \mathrm{Ca}_{0.47}\right)$ $\left[\left(\mathrm{UO}_{2}\right)_{3} \mathrm{O}_{2.84}(\mathrm{OH})_{2}\right]_{2} \cdot 5 \mathrm{H}_{2} \mathrm{O}$.

\subsection{Single-crystal X-ray diffraction}

Using single-crystal X-ray diffraction we studied a fragment of the tabular crystal of agrinierite from the Margnac deposit. The crystal of $0.122 \times 0.072 \times 0.020 \mathrm{~mm}$ dimensions was examined at room temperature using a Rigaku SuperNova single-crystal diffractometer. The diffraction experiment was carried out using Mo $K \alpha$ radiation $(\lambda=0.71073 \AA$ ) from a micro-focus X-ray tube, collimated and monochromated by mirror optics and detected by an Atlas S2 CCD detector using binning of $2 \times 2$ pixels and a high-gain mode to register even very weak reflections with an acceptable resolution.
Rameauite was studied using the same instrument; details can be found in the paper by Plášil et al. (2016). Here, we reanalyzed the diffraction data and conducted a new crystal structure refinement. The experimental and refinement details are reported in Table 1.

\section{Results}

\subsection{Twinning}

The diffraction experiment revealed an $F$-centered orthorhombic unit cell similar to that reported by Cahill \& Burns (2000). The initial refinements, using their structure model, led only to a fit with $R \simeq 8 \%$ and a GOF $>2.5$. The indexing procedure and unit-cell search in CrysAlis (Rigaku, 2019) did not return satisfactory unambiguous solutions. Therefore we undertook an indexing procedure implemented in Jana2006 (Tools $\rightarrow$ GrIndex, using the . tabbin reflection file from peakhunt; Petříček et al., 2014). This procedure revealed a monoclinic unit cell with $a=10.0400$ (3), $b=24.2211$ (8), $c=$ $10.4020(3) \AA, \beta=90.628(3)^{\circ}$ and $V \simeq 2411.42 \AA^{3}$, indexing about $90.4 \%$ of 21813 reflections. The monoclinic angle close to $90^{\circ}$ provides a warning of the possibility of metric merohedral twinning. The test quickly revealed the possibility of twin presence (represented by the mirror in [101]), leading to a supercell with $a=14.121, b=14.276, c=24.221 \AA$ and $V=2 \times$ $2441.42 \AA^{3}$, which is $F$ centered. The monoclinic $I$-centered cell, $a=13.9653$ (2), $b=14.22243$ (16), $c=13.9675$ (2) $\AA, \beta=$ $119.515(2)^{\circ}$ (selected to be similar to that of rameauite) was 
Table 2

Atom coordinates, isotropic and equivalent displacement parameters $(\AA)$, and site-occupancies for agrinierite.

\begin{tabular}{|c|c|c|c|c|}
\hline Atom & $x / a$ & $y / b$ & $z / c$ & $U_{\text {iso }} * / U_{\text {eq }}$ \\
\hline U1 & 0.371711 & 0.759536 & 0.616595 & $0.0129(5)$ \\
\hline $\mathrm{U} 2$ & 0.1928 (3) & 0.73988 (5) & $0.25716(7)$ & $0.013(6)$ \\
\hline U3 & 0.49507 (17) & $0.7501(2)$ & 0.4369 (2) & $0.0132(5)$ \\
\hline U4 & 0.37008 (12) & $0.27269(11)$ & $0.11730(11)$ & $0.0122(5)$ \\
\hline U5 & 0.48845 (17) & $0.23312(3)$ & $0.9369(2)$ & $0.0124(4)$ \\
\hline U6 & $0.6896(2)$ & $0.77272(13)$ & $0.75662(13)$ & $0.0156(6)$ \\
\hline$M 1 \dagger$ & $0.3431(4)$ & 0 & $0.2494(5)$ & $0.028(2)$ \\
\hline$M 2 \dagger$ & $0.5324(5)$ & 0.5 & $0.6242(5)$ & $0.013(2)$ \\
\hline K1 & $0.2984(7)$ & 0 & $0.9361(14)$ & 0.033 (4) \\
\hline $\mathrm{K} 2 \dagger$ & $0.5259(7)$ & 1 & $0.5946(7)$ & $0.023(2)^{*}$ \\
\hline K3 & $0.3674(6)$ & 0.5 & $0.2524(7)$ & $0.0318(18)^{*}$ \\
\hline K4 & $0.8533(10)$ & 0 & $0.9345(11)$ & $0.076(6)$ \\
\hline O1 & 0.8224 (19) & $0.7678(7)$ & 0.937 (3) & $0.027(2)^{*}$ \\
\hline $\mathrm{O} 2$ & $0.4620(15)$ & 0.1083 (7) & 0.935 (3) & $0.0238(19) *$ \\
\hline $\mathrm{O} 3$ & 0.3304 (12) & 0.7403 (13) & $0.4431(18)$ & $0.017(3)^{*}$ \\
\hline $\mathrm{O} 4$ & 0.3569 (13) & $0.1534(12)$ & 0.1235 (13) & $0.021(4)^{*}$ \\
\hline O5 & $0.5224(17)$ & $0.631(2)$ & $0.4820(17)$ & $0.026(6)^{*}$ \\
\hline O6 & $0.4730(17)$ & $0.875(2)$ & $0.3874(16)$ & $0.021(5)^{*}$ \\
\hline $\mathrm{O} 7$ & 0.3965 (11) & $0.3964(11)$ & $0.1223(12)$ & $0.014(3)^{*}$ \\
\hline O8 & 0.4087 (15) & $0.6352(17)$ & $0.6341(14)$ & $0.011(4) *$ \\
\hline O9 & 0.0252 (12) & $0.7539(12)$ & $0.1116(12)$ & $0.014(3)^{*}$ \\
\hline $\mathrm{O} 10$ & $0.8480(12)$ & 0.7338 (11) & 0.7641 (11) & $0.012(3)^{*}$ \\
\hline O11 & 0.1689 (14) & $0.6167(15)$ & $0.2818(14)$ & $0.025(4) *$ \\
\hline $\mathrm{O} 12$ & $0.3426(15)$ & 0.8801 (15) & 0.5998 (14) & $0.024(4) *$ \\
\hline O13 & 0.6892 (14) & $0.7804(12)$ & $0.5586(14)$ & $0.015(4) *$ \\
\hline $\mathrm{O} 14$ & $0.053(2)$ & 0.6939 (18) & 0.8100 (19) & $0.022(6)^{*}$ \\
\hline O15 & $0.210(2)$ & $0.862(2)$ & $0.2340(18)$ & $0.030(6)^{*}$ \\
\hline O16 & $0.3597(11)$ & $0.6927(10)$ & $0.2751(10)$ & $0.013(3)^{*}$ \\
\hline O17 & 0.6544 (11) & $0.6446(12)$ & 0.7537 (12) & $0.016(3)^{*}$ \\
\hline O18 & $0.5188(16)$ & $0.3568(7)$ & 0.935 (3) & $0.0229(19)^{*}$ \\
\hline O19 & $0.5684(14)$ & 0.7034 (13) & $0.3192(14)$ & $0.020(4)^{*}$ \\
\hline $\mathrm{O} 20$ & $0.1810(16)$ & $0.7015(15)$ & $0.0650(16)$ & $0.011(5)^{*}$ \\
\hline $\mathrm{O} 21$ & $0.7125(14)$ & 0.8993 (14) & $0.7710(13)$ & $0.029(5)^{*}$ \\
\hline $\mathrm{O} 22$ & $0.5240(10)$ & $0.7855(9)$ & $0.6074(10)$ & $0.006(2)^{*}$ \\
\hline $\mathrm{O} 23$ & 0.3292 (18) & 0.5 & 0.4734 (19) & $0.036(6)^{*}$ \\
\hline $\mathrm{O} 24$ & $0.671(2)$ & 1 & $0.541(2)$ & $0.054(8)^{*}$ \\
\hline $\mathrm{O} 25$ & 0.5839 (19) & 0.5 & 0.3128 (19) & $0.037(6)^{*}$ \\
\hline $\mathrm{O} 26$ & 0.185 (2) & 0 & 0.059 (2) & $0.029(7)^{*}$ \\
\hline $\mathrm{O} 27$ & 0.5427 (19) & 0.5 & 0.8131 (19) & $0.026(6)^{*}$ \\
\hline $\mathrm{O} 28$ & $0.675(2)$ & 0 & $1.055(2)$ & $0.062(8)^{*}$ \\
\hline $\mathrm{O} 29$ & $0.482(2)$ & 0 & 0.179 (2) & $0.051(7)^{*}$ \\
\hline $\mathrm{O} 30$ & $0.503(2)$ & 0 & $0.774(2)$ & $0.051(7)^{*}$ \\
\hline O31 & $0.8303(18)$ & 0.5 & $0.4306(17)$ & $0.024(4)^{*}$ \\
\hline $\mathrm{O} 32$ & $0.7210(18)$ & 0.5 & 0.6618 (19) & $0.034(6)^{*}$ \\
\hline
\end{tabular}

$\dagger$ Refined occupancies: $\quad M 1 \quad 0.89$ (3) Sr/0.11 (3)Ca; $\quad$ M2 0.43 (3) $\mathrm{Sr} / 0.57$ (3)Ca; $\quad \mathrm{K} 2$ $0.76(2)$.

later transformed during the space-group test procedure in Jana2006 to $C 2 / m$ (14.0694 14.2203 13.9669 90120.23790 ; transformation matrix $\left.\left|\begin{array}{lllllllll}1 & 0 & 1 & 0 & 1 & 0 & \overline{1} & 0 & 0\end{array}\right|\right)$. By averaging in $C 2 / m$ we obtained 3501 reflections with an $R_{\text {int }}$ of $5.12 \%$ (redundancy of 6.59). The structure solution in SHELXT (Sheldrick, 2015) returned a single solution in $\mathrm{Cm}$ (Flack 0.24 by SHELXT output), which we subsequently refined, with twinning by metric merohedry along with an inversion twin (this involves three symmetry elements to describe the twinning properly). Nevertheless, the refinement was not straightforward. The difficulties were mainly caused by the $\mathrm{K}$ sites; for instance, only two (K1 and K4) of the four independent $\mathrm{K}$ sites could be refined using a harmonic approach to the atomic displacement parameters. Only one of the K sites allowed the use of an anisotropic description for the atomic displacement
Table 3

Selected interatomic distances $(\AA)$ in the structure of agrinierite.

\begin{tabular}{|c|c|c|c|c|c|}
\hline U1-O8 & $1.83(3)$ & $\mathrm{U} 2-\mathrm{O} 11$ & $1.845(15)$ & $\mathrm{U} 3-\mathrm{O} 5$ & $1.78(3)$ \\
\hline $\mathrm{U} 1-\mathrm{O} 12$ & $1.748(14)$ & $\mathrm{U} 2-\mathrm{O} 15$ & $1.80(3)$ & U3-O6 & $1.88(3)$ \\
\hline U1-O3 & $21(3)$ & $\mathrm{U} 2-\mathrm{O} 3$ & $33(2)$ & $\mathrm{U} 3-\mathrm{O} 3$ & $2.37(2)$ \\
\hline $\mathrm{U} 1-\mathrm{O} 10^{\mathrm{ii}}$ & 2.247 (16) & $\mathrm{U} 2-\mathrm{O} 9$ & $2.214(11)$ & $\mathrm{U} 3-\mathrm{O} 13$ & $2.418(12)$ \\
\hline $\mathrm{U} 1-\mathrm{O} 13^{\mathrm{ii}}$ & 2.343 (14) & $\mathrm{U} 2-\mathrm{O} 16$ & $2.335(16)$ & U3-O16 & 2.249 (11) \\
\hline $\mathrm{U} 1-\mathrm{O} 14^{\mathrm{iii}}$ & $2.70(2)$ & $\mathrm{U} 2-\mathrm{O} 19^{\mathrm{ii}}$ & 2.453 (17) & U3-O19 & $2.432(17)$ \\
\hline $\mathrm{U} 1-\mathrm{O} 22$ & $2.244(16)$ & $\mathrm{U} 2-\mathrm{O} 20$ & $2.66(3)$ & $\mathrm{U} 3-\mathrm{O} 22$ & $2.256(15)$ \\
\hline$\left\langle\mathrm{U} 1-\mathrm{O}_{\mathrm{Ur}}\right\rangle$ & 1.79 & $\left\langle\mathrm{U} 2-\mathrm{O}_{\mathrm{Ur}}\right\rangle$ & 1.82 & $\left\langle\mathrm{U} 3-\mathrm{O}_{\mathrm{Ur}}\right\rangle$ & 1.83 \\
\hline$\left\langle\mathrm{U} 1-\mathrm{O}_{\mathrm{eq}}\right\rangle$ & 2.35 & $\left\langle\mathrm{U} 2-\mathrm{O}_{\mathrm{eq}}\right\rangle$ & 2.40 & $\left\langle\mathrm{U} 3-\mathrm{O}_{\mathrm{eq}}\right\rangle$ & 2.35 \\
\hline $\mathrm{U} 4-\mathrm{O} 4$ & $1.720(14)$ & $\mathrm{U} 5-\mathrm{O} 2$ & $1.811(11)$ & U6-O17 & $1.879(14)$ \\
\hline U4-O7 & & U5-C & & & \\
\hline $\mathrm{U} 4-\mathrm{O} 1^{\mathrm{vii}}$ & 2.26( & $\mathrm{U} 5-\mathrm{O} 1^{\mathrm{ix}}$ & ) & U6-O1 & $2.26(3)$ \\
\hline $\mathrm{U} 4-\mathrm{O} 9^{\text {viii }}$ & 2.233 (16) & $\mathrm{U} 5-09^{\mathrm{x}}$ & $2.251(15)$ & U6-O10 & $2.247(16)$ \\
\hline $\mathrm{U} 4-\mathrm{O} 16^{\mathrm{i}}$ & $2.329(16)$ & $\mathrm{U} 5-\mathrm{O} 10^{\mathrm{ix}}$ & $2.220(11)$ & U6-O13 & $2.758(16)$ \\
\hline $\mathrm{U} 4-\mathrm{O} 19^{\mathrm{i}}$ & 2.812 & $\mathrm{U} 5-\mathrm{O} 1$ & $2.43(3)$ & $\mathrm{U} 6-\mathrm{O} 14^{\mathrm{iii}}$ & $2.43(3)$ \\
\hline $\mathrm{U} 4-\mathrm{O} 20^{\mathrm{i}}$ & 2.41 & $\mathrm{U} 5-\mathrm{O} 2$ & 2.42( & $\mathrm{U} 6-\mathrm{O} 2$ & $2.219(1$ \\
\hline$\left\langle\mathrm{U} 4-\mathrm{O}_{\mathrm{Ur}}\right\rangle$ & 1.75 & $\langle\mathrm{U} 5-\mathrm{O}$ & 1.81 & $\langle\mathrm{U} 6-\mathrm{C}$ & 1.85 \\
\hline$\left\langle\mathrm{U} 4-\mathrm{O}_{\mathrm{eq}}\right\rangle$ & 2.35 & $\left\langle\mathrm{U} 5-\mathrm{O}_{\mathrm{eq}}\right\rangle$ & 2.34 & $\left\langle\mathrm{U} 6-\mathrm{O}_{\mathrm{eq}}\right\rangle$ & 2.38 \\
\hline $11-\mathrm{O} 4$ & & & & & \\
\hline$M 1-\mathrm{O} 4^{\mathrm{xii}}$ & $2.861(16)$ & $M 2-\mathrm{O}^{\mathrm{i}}$ & & & \\
\hline$M 1-\mathrm{O}^{\mathrm{xiii}}$ & $2.58(2)$ & $M 2-\mathrm{O} 8$ & $2.64(3)$ & $\mathrm{K} 1-\mathrm{O} 4^{\mathrm{xv}}$ & $3.182(14)$ \\
\hline$M 1-\mathrm{O}^{\mathrm{i}}$ & $2.58(2)$ & $M 2-O 8^{\mathrm{i}}$ & $2.64(3)$ & $\mathrm{K} 1-\mathrm{O} 4^{\mathrm{xvi}}$ & 3.182 (14) \\
\hline$M 1-\mathrm{O} 15^{\mathrm{xiii}}$ & 2.65 & $M 2-\mathrm{O} 17$ & 2.710 & $\mathrm{~K} 1-\mathrm{O} 17^{\mathrm{x}}$ & 3.105 (14) \\
\hline$M 1-\mathrm{O} 15^{\mathrm{i}}$ & 2.65 & $M 2-\mathrm{O}$ & 2.710 & $\mathrm{~K} 1-\mathrm{O} 1$ & 3.105 (14) \\
\hline$M 1-\mathrm{O} 2$ & 2.46 & $M 2-\mathrm{O}$ & .56 & $\mathrm{~K} 1-\mathrm{C}$ & 2.87 (4) \\
\hline$M 1-\mathrm{O} 29$ & $2.59(4)$ & $M 2-\mathrm{O}$ & $2.57(3)$ & $\mathrm{K} 1-\mathrm{O} 27^{\mathrm{x}}$ & $3.11(3)$ \\
\hline$M 1-\mathrm{O} 31^{\mathrm{x}}$ & $2.63(3)$ & $M 2-\mathrm{O} 32$ & $2.43(3)$ & $\mathrm{K} 1-\mathrm{O} 29^{\mathrm{xv}}$ & $3.06(2)$ \\
\hline \multirow[t]{2}{*}{$\langle M 1-\mathrm{O}\rangle$} & 2.65 & $\langle M 2-\mathrm{O}\rangle$ & 2.62 & $\mathrm{~K} 1-\mathrm{O} 32^{\mathrm{x}}$ & $3.41(3)$ \\
\hline & & & & $\langle\mathrm{K} 1-\mathrm{O}\rangle$ & 3.19 \\
\hline & & & & $\mathrm{K} 4-\mathrm{O} 1^{\mathrm{xiii}}$ & \\
\hline $\mathrm{K} 2-\mathrm{O}^{\mathrm{xvii}}$ & 3.15 & $\mathrm{~K} 3-\mathrm{O}^{\mathrm{i}}$ & 3.39 & $\mathrm{~K} 4-\mathrm{O} 1^{\mathrm{i}}$ & $3.334(11$ \\
\hline $\mathrm{K} 2-\mathrm{O} 12$ & $3.12(3)$ & & $2.531(18)$ & $\mathrm{K} 4-\mathrm{O}^{\mathrm{xi}}$ & 2.801 (19) \\
\hline $\mathrm{K} 2-\mathrm{O} 12^{\mathrm{xvii}}$ & $3.12(3)$ & $\mathrm{K} 3-\mathrm{O}^{\mathrm{i}}$ & & $\mathrm{K} 4-\mathrm{O}^{\mathrm{xix}}$ & 2.801 (19) \\
\hline K2-O21 & $2.921(13)$ & K3-O11 & 3.449 (18) & $\mathrm{K} 4-\mathrm{O} 18^{\text {viii }}$ & 3.09 (2) \\
\hline $\mathrm{K} 2-\mathrm{O} 21^{\mathrm{xvii}}$ & 2.921 (13) & $\mathrm{K} 3-\mathrm{O} 11^{\mathrm{i}}$ & 3.449 (18) & $\mathrm{K} 4-\mathrm{O} 18^{\mathrm{xx}}$ & $3.09(2)$ \\
\hline $\mathrm{K} 2-\mathrm{O} 22$ & $3.056(13)$ & K3-O16 & $2.771(14)$ & $\mathrm{K} 4-\mathrm{O} 21^{\mathrm{xiii}}$ & 2.571 (14) \\
\hline $\mathrm{K} 2-\mathrm{O} 22^{\mathrm{xvii}}$ & $3.056(13)$ & $\mathrm{K} 3-\mathrm{O} 16^{\mathrm{i}}$ & $2.771(14)$ & $\mathrm{K} 4-\mathrm{O} 21^{\mathrm{i}}$ & $2.571(14)$ \\
\hline $\mathrm{K} 2-\mathrm{O} 24$ & 2.50 (4) & & 3.39 (3) & $\mathrm{K} 4-\mathrm{O} 27^{\mathrm{ix}}$ & $3.81(4)$ \\
\hline $\mathrm{K} 2-\mathrm{O} 30^{\mathrm{iv}}$ & $2.68(3)$ & $\mathrm{K} 3-\mathrm{O} 25$ & $2.72(3)$ & $\mathrm{K} 4-\mathrm{O} 28$ & $3.66(10)$ \\
\hline $\mathrm{K} 2-\mathrm{O} 31^{\mathrm{v}}$ & $2.54(2)$ & $\mathrm{K} 3-\mathrm{O} 28^{\mathrm{vi}}$ & $2.72(2)$ & $\langle\mathrm{K} 4-\mathrm{O}\rangle$ & 3.11 \\
\hline$\langle\mathrm{K} 2-\mathrm{O}\rangle$ & 2.93 & $\langle\mathrm{~K} 3-\mathrm{O}\rangle$ & 2.99 & & \\
\hline
\end{tabular}

Symmetry codes: (i) $x,-y+1, z$; (ii) $x-\frac{1}{2},-y+\frac{3}{2}, z$; (iii) $x+\frac{1}{2},-y+\frac{3}{2}, z$; (iv) $x-\frac{1}{2}, y+\frac{1}{2}$, $z$; (v) $x-\frac{1}{2}, y+\frac{1}{2}, z-1$; (vii) $x-\frac{1}{2}, y-\frac{1}{2}, z-1$; (viii) $x+\frac{1}{2}, y-\frac{1}{2}, z$; (ix) $x-\frac{1}{2}, y-\frac{1}{2}, z$; (x) $x+\frac{1}{2}, y-\frac{1}{2}, z+1$; (xi) $x,-y, z$; (xii) $x, y-1, z$; (xiii) $x-\frac{1}{2},-y+\frac{1}{2}, z$; (xiv) $x, y, z+1$; (xv) $x,-y, z+1$; (xvi) $x,-y+2, z$; (xviii) $x, y+1, z$; (xix) $x+\frac{1}{2},-y+\frac{1}{2}, z+1$; (xx) $x+\frac{1}{2},-y+\frac{1}{2}, z$; (xxi) $x+\frac{1}{2}, y+\frac{1}{2}, z+1$

parameters, and one of the $\mathrm{K}$ sites was found to have a lower occupancy than unity (K2; Table 2). Nevertheless, the refined occupancies and atomic displacement parameters are probably still greatly affected by the complete overlap of reflections as a result of twinning. For the final cycle of the refinement, the $x y z$ coordinates of the $\mathrm{U} 1$ atom were fixed due to correlations. The final refinement (Table 1) for the agrinierite twinned crystal converged to $R=3.54 \%$ for 6545 unique observed reflections, with $I>3 \sigma(I)$ and $\mathrm{GOF}=1.07$. The final atomic coordinates and displacement parameters for agrinierite are provided in Table 2, selected interatomic distances in Table 3 and a bond-valence analysis in Table 4. The bond-valence analysis was carried out following the procedure by Brown $(2002,2009)$ using bond-valence parameters provided by Gagné \& Hawthorne (2015). 
Table 4

Bond-valence analysis (all values given in valence units, vu) for agrinierite.

The bond-valence parameters were taken from Gagné \& Hawthorne (2015). H - including a contribution of donor-hydrogen bonds; $n \mathrm{H}$ - maximum number of possible weak $\mathrm{H} \cdots$ acceptor bonds to a particular site. Idealized bond strengths were taken from Brown (2002). Donor-H $(0.8 \mathrm{vu}), \mathrm{H} \cdots$ acceptor $(0.2 \mathrm{vu})$. Site occupancies considered.

\begin{tabular}{|c|c|c|c|c|c|c|c|c|c|c|c|c|c|c|c|}
\hline & U1 & U2 & U3 & U4 & U5 & U6 & $M 1$ & $M 2$ & K1 & $\mathrm{K} 2$ & K3 & K4 & Sum & $\operatorname{Sum}^{\mathrm{H}}$ & $n \mathrm{H}$ \\
\hline O1 & & & & 0.64 & 0.48 & 0.64 & & & 0.02 & & & 0.08 & 1.86 & 1.86 & 1 \\
\hline $\mathrm{O} 2$ & & & & & 1.64 & & & & 0.32 & & & & 1.96 & 1.96 & 0 \\
\hline $\mathrm{O} 3$ & 0.71 & 0.55 & 0.50 & & & & & & & & & & 1.76 & 1.76 & 1 \\
\hline $\mathrm{O} 4$ & & & & 1.99 & & & 0.29 & & 0.12 & & & & 2.20 & 2.20 & 0 \\
\hline O5 & & & 1.75 & & & & & 0.37 & & & 0.07 & & 1.93 & 1.93 & 0 \\
\hline O6 & & & 1.42 & & & & 0.53 & & & 0.10 & & & 1.72 & 1.72 & 1 \\
\hline O7 & & & & 1.74 & & & & & & & 0.59 & 0.30 & 2.18 & 2.18 & 0 \\
\hline $\mathrm{O} 8$ & 1.58 & & & & & & & 0.40 & & & & & 1.78 & 1.78 & 1 \\
\hline O9 & & 0.70 & & 0.67 & 0.65 & & & & & & & & 2.02 & 2.02 & 0 \\
\hline $\mathrm{O} 10$ & 0.65 & & & & 0.69 & 0.65 & & & & & & & 2.00 & 2.00 & 0 \\
\hline O11 & & 1.53 & & & & & & & & & 0.06 & & 1.59 & 1.59 & 2 \\
\hline $\mathrm{O} 12$ & 1.88 & & & & & & & & & 0.10 & & & 1.93 & 1.93 & 0 \\
\hline O13 & 0.53 & & 0.46 & & & 0.22 & & & & & & & 1.21 & 2.01 & 0 \\
\hline O14 & 0.25 & & & & 0.44 & 0.44 & & & & & & & 1.14 & 1.94 & 0 \\
\hline O15 & & 1.68 & & & & & 0.46 & & & & & & 1.91 & 1.91 & 0 \\
\hline O16 & & 0.54 & 0.65 & 0.55 & & & & & & & 0.32 & & 1.91 & 1.91 & 0 \\
\hline O17 & & & & & & 1.42 & & 0.34 & 0.14 & & & & 1.66 & 1.66 & 2 \\
\hline O18 & & & & & 1.63 & & & & & & & 0.15 & 1.71 & 1.71 & 1 \\
\hline O19 & & 0.42 & 0.44 & 0.20 & & & & & & & & & 1.06 & 1.86 & 1 \\
\hline $\mathrm{O} 20$ & & 0.27 & & 0.46 & 0.45 & & & & & & & & 1.19 & 1.99 & 0 \\
\hline $\mathrm{O} 21$ & & & & & & 1.62 & & & & 0.17 & & 0.54 & 1.97 & 1.97 & 0 \\
\hline $\mathrm{O} 22$ & 0.66 & & 0.64 & & & 0.69 & & & & 0.12 & & & 2.05 & 2.05 & 0 \\
\hline $\mathrm{O} 23$ & & & & & & & & 0.24 & & & 0.03 & & 0.27 & 1.87 & 1 \\
\hline $\mathrm{O} 24$ & & & & & & & & & & 0.24 & & & 0.24 & 2.04 & 0 \\
\hline $\mathrm{O} 25$ & & & & & & & & & & & 0.18 & & 0.18 & 1.78 & 1 \\
\hline O26 & & & & & & & 0.34 & & 0.13 & & & & 0.47 & 2.07 & 0 \\
\hline $\mathrm{O} 27$ & & & & & & & & 0.23 & 0.07 & & & 0.01 & 0.31 & 1.91 & 0 \\
\hline $\mathrm{O} 28$ & & & & & & & & & & & 0.18 & 0.02 & 0.20 & 1.80 & 1 \\
\hline O29 & & & & & & & 0.26 & & 0.08 & & & & 0.34 & 1.94 & 0 \\
\hline O30 & & & & & & & & & & 0.15 & & & 0.15 & 1.75 & 1 \\
\hline O31 & & & & & & & 0.24 & & & 0.22 & & & 0.46 & 2.06 & 0 \\
\hline O32 & & & & & & & & 0.32 & 0.03 & & & & 0.35 & 1.95 & 0 \\
\hline Sum & 6.26 & 5.70 & 5.87 & 6.25 & 6.00 & 5.69 & 2.11 & 1.90 & 0.90 & 1.11 & 1.45 & 1.09 & & & \\
\hline
\end{tabular}

twin, returned meaningful values. The final refinement converged to $R=4.24 \%$ for 2344 unique observed reflections with $I>3 \sigma(I)$ and $\mathrm{GOF}=1.48$. Statistical details for the refinement are given in Table 1 . Final atom coordinates and displacement parameters for agrinierite are listed in Table 5, selected interatomic distances in Table 6 and a bondvalence analysis in Table 7 . The bond-valence analysis was performed following the procedure by Brown (2002, 2009) using bond-valence parameters provided by Gagné \& Hawthorne (2015).

Twin contributions for both minerals were evaluated also visually using the reciprocal layer reconstructions retrieved from the diffraction frames (the UNWARP tool within the CrysAlis software) and by computer methods using the program Jana2020 (Figs. 2). We have chosen the best representatives for twinning in both minerals to be displayed. Figs. 2(a) and 2(b) display the $h 1 l$ layer of the reciprocal space in agrinierite, with apparently all reflections overlapping. This makes the recognition of the twin presence relatively difficult, at least more difficult than in the case of rameauite [Figs. 2(c) and $2(d)]$. Although the diffraction intensities are vastly affected by the twin contributions, at least some of the observed reflections that are diagnostic (e.g. Petř́íček et al., 2016), i.e. warning us of twinning, are 'visible' (i.e. are not completely overlapping as in the case of agrinierite).

For the evaluation of the twin type studied here, it is both necessary and useful to transform

Subsequently, the structure of rameauite was reinvestigated and tested for twinning presence, following the same procedure as for agrinierite. We used the same reflection file as used in the study by Plášil et al. (2016), but we reprocessed it with a newer version of the CrysAlis software (version 40.64.67a). We employed a new structure solution and refinement using this reflection file for consistency [we emphasize that by using the original reflection file from the study by Plášil et al. (2016) and a twin-handling procedure in the current version of the Jana software (Jana2020), several problems occur, which can simply be overcome by using newly processed reflection files from the original diffraction frames]. The unit cell of rameauite, $a=$ 13.947 (3), $b=14.300$ (3), $c=13.888$ (3) $\AA, \beta=118.50$ (3) ${ }^{\circ}$ with $V=2434.3(11) \AA^{3}$, aligns with previous work (Plášil et al., 2016). The structure was solved using SHELXT in the monoclinic space group $C c$ (Flack 0.42 by SHELXT output). The structure refinement involved an inversion twin due to merohedry and, in the final stages, also a reticular twin contribution, finally featuring eight twin elements (due to the group $>$ subgroup relationship between tetragonal $>$ monoclinic symmetry groups). As some of the twin-domain fractions returned slightly negative values they were fixed to 0 ; the rest of the refined twin fractions, mirror in $(\overline{101})$ and inversion the $C$-centered unit cells into primitive ones. Otherwise, the results of the test for the higher-symmetry cell in Jana2020 will give correct results in terms of the searched cell, but the twin matrices will be applied to the conditions of the cell centering of our choice (and thus could be different from those without the applied conditions for centering and the systematic absences of reflections for the chosen space group). After $C \rightarrow P$ cell transformation the twin matrix of the mirror element for agrinierite is $\left|\begin{array}{lllllll}1 & 0 & 0\end{array}\right| \begin{array}{lll}0 & 1 & 0\end{array}\left|\begin{array}{lll}1 & 0 & \overline{1}\end{array}\right|$, a mirror in (102), and for rameauite is $|1 / 2 \overline{1 / 2} 1 / 2| \overline{1 / 2} 1 / 21 / 2|1 \quad 10|$, a mirror in (111). Therefore, as the twin matrix for rameauite contains non-rational numbers, it appears to be twinned by reticular merohedry with apparent obliquity (diffraction type II). Agrinierite, with a matrix containing only rational numbers, thus appears to be twinned by metric merohedry [diffraction type I; see Petř́ícek et al. (2016) for details]. To conclude, this is also the main reason for the distinct diffraction patterns of agrinierite [Figs. 2(a) and 2(b)] and rameauite [Figs. 2(c) and $2(d)]$. In the case of agrinierite all reflections overlap (all displayed in red in the simulated pattern), whereas for agrinierite, they are separated (red and green) and form the pattern characteristic for this type of twin (we can call it an 'hourglass'-like pattern; Petř́čck et al., 2016). 
Table 5

Atom coordinates and isotropic and equivalent displacement parameters (A) for rameauite.

\begin{tabular}{lllll}
\hline Atom & $x / a$ & $y / b$ & $z / c$ & $U_{\text {iso }} * / U_{\text {eq }}$ \\
\hline U1 & $0.2214(11)$ & $0.50151(9)$ & $0.1010(10)$ & $0.0168(6)$ \\
U2 & $0.0881(11)$ & $0.52239(9)$ & $0.2828(10)$ & $0.0196(6)$ \\
U3 & $0.2102(11)$ & $0.00417(9)$ & $0.0935(10)$ & $0.0173(5)$ \\
U4 & $0.4099(11)$ & $0.51689(10)$ & $0.4037(10)$ & $0.0173(5)$ \\
U5 & $0.0692(11)$ & $-0.01326(10)$ & $0.2565(10)$ & $0.0170(6)$ \\
U6 & $0.9025(11)$ & $0.51586(10)$ & $0.9074(10)$ & $0.0185(6)$ \\
Ca1 & $0.0961(13)$ & $0.2526(6)$ & $0.1526(12)$ & $0.031(3)$ \\
K1 & $0.2419(13)$ & $0.7507(6)$ & $0.2578(12)$ & $0.035(3)$ \\
O1 & $0.200(2)$ & $0.3786(16)$ & $0.123(2)$ & $0.027(6)^{*}$ \\
O2 & $0.076(2)$ & $0.5070(19)$ & $0.429(2)$ & $0.026(6)^{*}$ \\
O3 & $0.092(2)$ & $0.6491(13)$ & $0.297(2)$ & $0.015(4)^{*}$ \\
K2 & $0.0953(14)$ & $0.7511(7)$ & $0.9147(13)$ & $0.037(4)$ \\
O4 & $0.395(2)$ & $0.4876(16)$ & $0.2248(19)$ & $0.023(6)^{*}$ \\
O5 & $0.579(2)$ & $0.5040(17)$ & $0.9191(19)$ & $0.019(5)^{*}$ \\
O6 & $0.539(2)$ & $0.5270(17)$ & $0.584(2)$ & $0.018(5)^{*}$ \\
O7 & $0.038(2)$ & $0.5519(17)$ & $0.0945(19)$ & $0.024(5)^{*}$ \\
O8 & $0.238(2)$ & $0.5312(18)$ & $0.266(2)$ & $0.026(6)^{*}$ \\
O9 & $0.899(2)$ & $0.5389(17)$ & $0.236(2)$ & $0.024(6)^{*}$ \\
O10 & $0.028(2)$ & $0.747(2)$ & $0.084(2)$ & $0.033(7)^{*}$ \\
O11 & $0.283(2)$ & $0.5487(17)$ & $0.4747(19)$ & $0.031(5)^{*}$ \\
O12 & $0.240(2)$ & $0.623(2)$ & $0.082(2)$ & $0.037(7)^{*}$ \\
O13 & $0.892(3)$ & $0.396(2)$ & $0.942(3)$ & $0.052(9)^{*}$ \\
O14 & $0.419(2)$ & $0.8612(14)$ & $0.3798(19)$ & $0.015(5)^{*}$ \\
O15 & $0.735(2)$ & $0.518(2)$ & $0.763(2)$ & $0.038(7)^{*}$ \\
O16 & $0.081(2)$ & $0.3996(17)$ & $0.258(2)$ & $0.029(7)^{*}$ \\
O17 & $0.191(2)$ & $0.1289(15)$ & $0.110(2)$ & $0.022(5)^{*}$ \\
O18 & $0.073(2)$ & $0.1140(14)$ & $0.250(2)$ & $0.018(5)^{*}$ \\
O19 & $0.393(3)$ & $0.3907(17)$ & $0.420(2)$ & $0.031(6)^{*}$ \\
O20 & $0.253(3)$ & $0.2505(17)$ & $0.334(3)$ & $0.033(6)^{*}$ \\
O21 & $0.049(3)$ & $0.2527(18)$ & $-0.039(2)$ & $0.041(8)^{*}$ \\
O22 & $-0.111(3)$ & $0.7486(18)$ & $0.217(3)$ & $0.035(7)^{*}$ \\
O23 & $0.244(2)$ & $-0.1166(19)$ & $0.087(2)$ & $0.020(6)^{*}$ \\
O24 & $0.422(2)$ & $0.6448(16)$ & $0.391(2)$ & $0.031(6)^{*}$ \\
O25 & $0.073(2)$ & $-0.1438(15)$ & $0.2669(18)$ & $0.024(6)^{*}$ \\
O26 & $0.795(2)$ & $0.5542(16)$ & $0.9874(19)$ & $0.028(5)^{*}$ \\
O27 & $-0.231(2)$ & $0.7514(19)$ & $0.018(2)$ & $0.035(7)^{*}$ \\
O28 & $-0.086(3)$ & $0.254(2)$ & $0.127(3)$ & $0.055(8)^{*}$ \\
\hline & & & &
\end{tabular}

\subsection{The refined structures of agrinierite and rameauite}

The current structure model of agrinierite leaves the findings of Cahill \& Burns (2000) about structure topology unchanged. Nevertheless, as the correct structure crystallizes in the monoclinic $\mathrm{Cm}$ space group, the single $\mathrm{M}^{2+}$-interlayer site in the model by Cahill \& Burns (2000) is split into two symmetry non-equivalent sites. Moreover, Cahill \& Burns (2000) restrained the occupation for $\mathrm{Ca}$ and $\mathrm{Sr}$. The current model indicates that, while at one site (designated as $M 1$ ) $\mathrm{Sr}$ is prevailing over $\mathrm{Ca}$, at the second site $(M 2) \mathrm{Ca}$ is slightly prevailing (Table 2). Therefore, we report the formula of agrinierite comprising two $M^{2+}$ sites as $\mathrm{K}_{3.758}\left(\mathrm{Sr}_{0.89} \mathrm{Ca}_{0.11}\right)$ $\left(\mathrm{Ca}_{0.57} \mathrm{Sr}_{0.43}\right)\left[\left(\mathrm{UO}_{2}\right)_{3} \mathrm{O}_{3}(\mathrm{OH})_{2}\right]_{4} \cdot 10 \mathrm{H}_{2} \mathrm{O}, Z=2$. This formula is not electroneutral, having a 0.121 negative charge surplus; the scattering contribution of the $\mathrm{K}$ atoms, namely displacement parameters and occupation factors, is still probably vastly affected by twinning.

The same occurs for the structure model of rameauite, leaving the model proposed earlier by Plášil et al. (2016) unchanged in general. The fit to the data is better overall, as it can also be documented by the root-mean-squared deviation of the final bond-valence sums of the oxygen atoms within the
Table 6

Selected interatomic distances $(\AA)$ in the structure of rameauite.

\begin{tabular}{|c|c|c|c|c|c|}
\hline U1-O1 & $1.83(3)$ & $\mathrm{U} 2-\mathrm{O} 3$ & $1.819(15)$ & $\mathrm{U} 3-\mathrm{O} 17$ & $1.83(3)$ \\
\hline $\mathrm{U} 1-\mathrm{O} 12$ & $1.80(3)$ & $\mathrm{U} 2-\mathrm{O} 16$ & $1.78(3)$ & $\mathrm{U} 3-\mathrm{O} 23$ & $1.81(3)$ \\
\hline $\mathrm{U} 1-\mathrm{O} 2^{\mathrm{i}}$ & $2.28(2)$ & $\mathrm{U} 2-\mathrm{O} 7$ & $2.41(3)$ & $\mathrm{U} 3-\mathrm{O}^{\mathrm{vii}}$ & $2.24(2)$ \\
\hline $\mathrm{U} 1-\mathrm{O} 4$ & $2.21(2)$ & $\mathrm{U} 2-\mathrm{O} 8$ & $2.22(4)$ & $\mathrm{U} 3-\mathrm{O}^{\mathrm{vi}}$ & $2.36(3)$ \\
\hline $\mathrm{U} 1-\mathrm{O} 7$ & $2.61(3)$ & $\mathrm{U} 2-\mathrm{O} 9^{\mathrm{iv}}$ & $2.41(3)$ & $\mathrm{U} 3-\mathrm{O}^{\mathrm{v}}$ & $2.47(2)$ \\
\hline $\mathrm{U} 1-\mathrm{O} 8$ & $2.23(3)$ & $\mathrm{U} 2-\mathrm{O} 11$ & $2.78(2)$ & $\mathrm{U} 3-\mathrm{O} 15^{\mathrm{vi}}$ & $2.22(3)$ \\
\hline $\mathrm{U} 1-\mathrm{O} 11^{\mathrm{i}}$ & $2.40(4)$ & $\left\langle\mathrm{U} 2-\mathrm{O}_{\mathrm{Ur}}\right\rangle$ & 1.80 & $\mathrm{U} 3-\mathrm{O} 26^{\mathrm{vii}}$ & $2.41(4)$ \\
\hline$\left\langle\mathrm{U} 1-\mathrm{O}_{\mathrm{Ur}}\right\rangle$ & 1.81 & $\left\langle\mathrm{U} 2-\mathrm{O}_{\mathrm{eq}}\right\rangle$ & 2.39 & $\left\langle\mathrm{U} 3-\mathrm{O}_{\mathrm{Ur}}\right\rangle$ & 1.82 \\
\hline$\left\langle\mathrm{U} 1-\mathrm{O}_{\mathrm{eq}}\right\rangle$ & 2.35 & & & $\left\langle\mathrm{U} 3-\mathrm{O}_{\mathrm{eq}}\right\rangle$ & 2.34 \\
\hline U4-O19 & $1.84(3)$ & U5-O18 & $1.825(15)$ & U6-O13 & $1.81(3)$ \\
\hline $\mathrm{U} 4-\mathrm{O} 24$ & $1.86(3)$ & $\mathrm{U} 5-\mathrm{O} 25$ & $1.87(3)$ & $\mathrm{U} 6-\mathrm{O} 14^{\mathrm{ix}}$ & $1.839(18)$ \\
\hline $\mathrm{U} 4-\mathrm{O} 4$ & $2.43(3)$ & $\mathrm{U} 5-\mathrm{O}_{4}^{\mathrm{v}}$ & $2.25(3)$ & $\mathrm{U} 6-\mathrm{O}^{\mathrm{x}}$ & $2.32(3)$ \\
\hline $\mathrm{U} 4-\mathrm{O}^{\mathrm{i}}$ & $2.28(3)$ & $\mathrm{U} 5-\mathrm{O}^{\mathrm{vi}}$ & 2.19 (3) & $\mathrm{U} 6-\mathrm{O}^{\mathrm{xi}}$ & $2.43(2)$ \\
\hline $\mathrm{U} 4-\mathrm{O} 6$ & $2.28(2)$ & $\mathrm{U} 5-\mathrm{O}^{\mathrm{vi}}$ & $2.24(3)$ & $\mathrm{U} 6-\mathrm{O} 9^{\mathrm{xii}}$ & $2.48(3)$ \\
\hline $\mathrm{U} 4-\mathrm{O} 8$ & $2.25(2)$ & $\mathrm{U} 5-\mathrm{O} 15^{\mathrm{vi}}$ & $2.28(3)$ & U6-O15 & $2.23(2)$ \\
\hline $\mathrm{U} 4-\mathrm{O} 11$ & $2.45(4)$ & $\left\langle\mathrm{U} 5-\mathrm{O}_{\mathrm{Ur}}\right\rangle$ & 1.85 & $\mathrm{U} 6-\mathrm{O} 26$ & $2.31(4)$ \\
\hline$\left\langle\mathrm{U} 4-\mathrm{O}_{\mathrm{Ur}}\right\rangle$ & 1.85 & $\left\langle\mathrm{U} 5-\mathrm{O}_{\mathrm{eq}}\right\rangle$ & 2.24 & $\left\langle\mathrm{U} 6-\mathrm{O}_{\mathrm{Ur}}\right\rangle$ & 1.83 \\
\hline$\left\langle\mathrm{U} 4-\mathrm{O}_{\mathrm{eq}}\right\rangle$ & 2.33 & & & $\left\langle\mathrm{U} 6-\mathrm{O}_{\mathrm{eq}}\right\rangle$ & 2.36 \\
\hline $\mathrm{Ca} 1-\mathrm{O} 1$ & $2.47(3)$ & $\mathrm{K} 1-\mathrm{O} 3$ & $2.80(3)$ & $\mathrm{K} 2-\mathrm{O}^{\mathrm{xvi}}$ & $3.63(3)$ \\
\hline $\mathrm{Ca} 1-\mathrm{O} 13^{\mathrm{ii}}$ & $3.60(3)$ & $\mathrm{K} 1-\mathrm{O} 8$ & 3.15 (3) & $\mathrm{K} 2-\mathrm{O} 10^{\mathrm{xvii}}$ & $2.91(4)$ \\
\hline $\mathrm{Ca} 1-\mathrm{O} 16$ & $2.63(3)$ & $\mathrm{K} 1-\mathrm{O} 10$ & $2.81(2)$ & $\mathrm{K} 2-\mathrm{O} 12^{\mathrm{xvii}}$ & 2.89 (3) \\
\hline $\mathrm{Ca} 1-\mathrm{O} 17$ & $2.45(3)$ & $\mathrm{K} 1-\mathrm{O} 12$ & $3.04(3)$ & $\mathrm{K} 2-\mathrm{O} 14^{\mathrm{xviii}}$ & 2.77 (3) \\
\hline $\mathrm{Ca} 1-\mathrm{O} 18$ & $2.50(3)$ & $\mathrm{K} 1-\mathrm{O} 14$ & $2.73(2)$ & $\mathrm{K} 2-\mathrm{O} 16^{\mathrm{xii}}$ & $3.01(3)$ \\
\hline $\mathrm{Ca}-\mathrm{O} 20$ & $2.42(3)$ & $\mathrm{K} 1-\mathrm{O} 15^{\mathrm{xiv}}$ & $3.31(3)$ & $\mathrm{K} 2-\mathrm{O} 18^{\mathrm{xii}}$ & $2.90(3)$ \\
\hline $\mathrm{Ca} 1-\mathrm{O} 21$ & $2.42(3)$ & $\mathrm{K} 1-\mathrm{O} 23^{\mathrm{xv}}$ & $3.05(3)$ & $\mathrm{K} 2-\mathrm{O} 20^{\mathrm{xii}}$ & $2.91(5)$ \\
\hline $\mathrm{Ca} 1-\mathrm{O} 28$ & $2.39(5)$ & $\mathrm{K} 1-\mathrm{O} 24$ & $2.75(3)$ & $\mathrm{K} 2-\mathrm{O} 23^{\mathrm{xix}}$ & $2.97(3)$ \\
\hline \multirow[t]{4}{*}{$\langle\mathrm{Ca} 1-\mathrm{O}\rangle$} & 2.61 & $\mathrm{~K} 1-\mathrm{O} 25^{\mathrm{xv}}$ & $2.85(3)$ & $\mathrm{K} 2-\mathrm{O} 24^{\mathrm{xviii}}$ & $2.72(3)$ \\
\hline & & $\mathrm{K} 1-\mathrm{O} 27^{\mathrm{ix}}$ & $2.95(3)$ & $\mathrm{K} 2-\mathrm{O} 28^{\mathrm{xii}}$ & 3.57 (4) \\
\hline & & $\langle\mathrm{K} 1-\mathrm{O}\rangle$ & 2.97 & $\mathrm{~K} 1-\mathrm{O} 33^{\mathrm{ix}}$ & $3.46(3)$ \\
\hline & & & & $\langle\mathrm{K} 1-\mathrm{O}\rangle$ & 3.03 \\
\hline
\end{tabular}

Symmetry codes: (i) $x,-y+1, z-\frac{1}{2}$; (ii) $x-1, y, z-1$; (iv) $x-1, y, z$; (v) $x-\frac{1}{2}, y-\frac{1}{2}, z$; (vi) $x-\frac{1}{2},-y+\frac{1}{2}, z-\frac{1}{2}$; (vii) $x-\frac{1}{2}, y-\frac{1}{2}, z-1$; (ix) $x+\frac{1}{2},-y+\frac{3}{2}, z+\frac{1}{2}$; (x) $x+1,-y+1, z+$ $\frac{1}{2}$; (xi) $x+1, y, z+1$; (xii) $x,-y+1, z+\frac{1}{2}$; (xiv) $x-\frac{1}{2},-y+\frac{3}{2}, z-\frac{1}{2}$; (xv) $x, y+1, z$; (xvi) $x-$ $\frac{1}{2}, y+\frac{1}{2}, z$; (xvii) $x, y, z+1$; (xviii) $x-\frac{1}{2},-y+\frac{3}{2}, z+\frac{1}{2}$; (xix) $x, y+1, z+1$.

structure (with the considered contribution of the $D-\mathrm{H}$ bonds, equal to $0.8 \mathrm{vu}$, for the $\mathrm{H}_{2} \mathrm{O}$ and $\mathrm{OH}$ groups equally for both rameauite structure models). For the structure model given by Plášil et al. (2016), this is $0.25 \mathrm{vu}$, and for the currently presented model it is $0.14 \mathrm{vu}$. The formula of rameauite, based on refined occupancies and bond-valence calculations, is $\mathrm{K}_{4} \mathrm{Ca}_{2}\left[\left(\mathrm{UO}_{2}\right)_{3} \mathrm{O}_{3}(\mathrm{OH})_{2}\right]_{4} \cdot 12 \mathrm{H}_{2} \mathrm{O}, Z=2$. We report the formula based on the same $Z$ as for agrinierite to obtain a better comparison.

4. Implications: the careful handling of structures with 'hidden' twinning

The two uranyl-oxide hydroxy-hydrate minerals presented here demonstrate how careful one must be when handling diffraction data affected by twinning. Agrinierite is representative of a structure providing a single-crystal diffraction pattern with hidden twinning. From the symmetry and diffraction intensities, it is difficult in this particular case to discover the twinning at first glance. Nevertheless, there are some general guides (e.g. Petř́íč et al., 2016; Plášil et al., 2021) that are still valid:

(1) Awkward cell centering (systematic absences generated by the twinning) for the given symmetry of the structure 

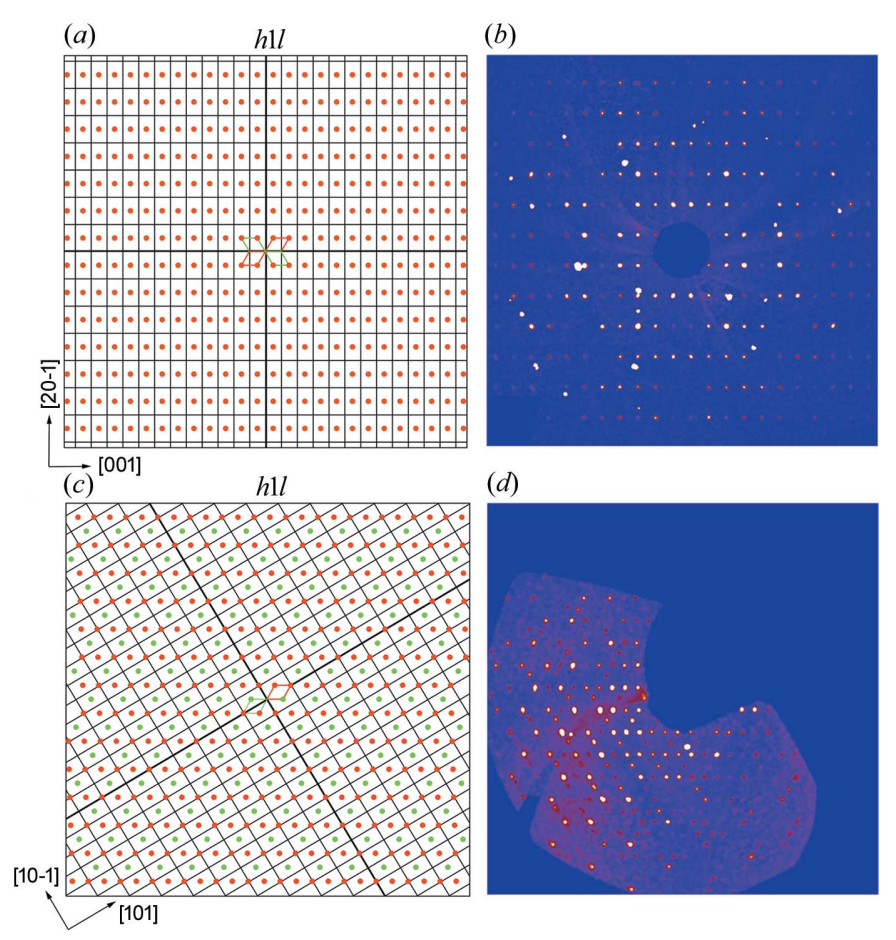

(d)

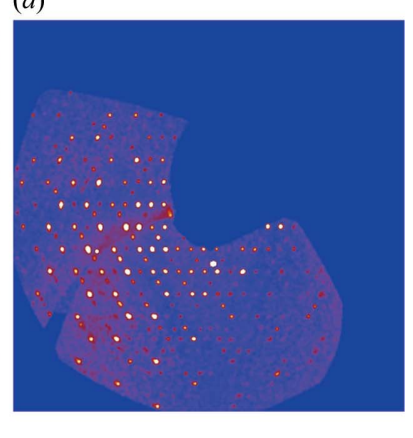

Figure 2

Single-crystal diffraction patterns of agrinierite and rameauite. (a) Simulated $h 1 l$ layer of the reciprocal space of agrinierite. Reflections from all domains overlap completely (i.e. 'hidden twinning') due to twinning by metric merohedry and generate an $F$-centered (pseudo)orthorhombic pattern (the black array corresponds to the unit cell given by the previous structure determination). (b) Reciprocal space reconstruction (UNWARP tool) of the $h 1 l$ layer from the experimental data for agrinierite. (c) Simulated $h 1 l$ layer of the reciprocal space of rameauite. Reflections for the two main domains overlap only partially, due to twinning by reticular merohedry. The array corresponds to the supercell. (d) Reciprocal space reconstruction (UNWARP tool) of the $h 1 l$ layer from the experimental data for rameauite.

affected by (unresolved) twinning. In the case of agrinierite it was an $F$-centered orthorhombic cell.

(2) Higher residuals. In the case of agrinierite $R_{\mathrm{obs}}>6 \%$ along with the overestimated fit ( $S$ value from $S H E L X<1$ for the given weighting scheme).

Nevertheless, the handling of the twinned structures might not be as straightforward as for the untwinned structures. The second example, rameauite, is an illustrative case. The twinning features present in the structure (as documented in this study) were simply overlooked by one of the authors (JP). We emphasize that the tolerance limits (for maximal deviations for cell lengths and angles) had to be increased during the test for reticular twinning in Jana2020 for rameauite (up to $0.25 \AA$ for cell lengths and $0.35^{\circ}$ for angles). Then the procedure found the supercell of the higher symmetry unambiguously. We recommend doing so for cases of the worst diffraction data quality (and 'worse' fitted unit-cell metrics, which could bias the algorithm). However, the presence has to be then verified every time by a reasonable and meaningful structure refinement. For complicated unusual cases, when ordinary indexing programs (like the algorithms in CrysAlis) for unit-cell search fail, we recommend using the Jana2020 built-in indexing
Table 7

Bond-valence analysis (all values given in vu) for rameauite.

The bond-valence parameters were taken from Gagné \& Hawthorne (2015). H - including a contribution of donor-hydrogen bonds; $n \mathrm{H}$ - maximum number of possible weak $\mathrm{H} \cdots$ acceptor bonds to the particular site. Idealized bond strengths were taken from Brown (2002) - donor-H $(0.8 \mathrm{vu}), \mathrm{H} \cdots$ acceptor $(0.2 \mathrm{vu})$.

\begin{tabular}{|c|c|c|c|c|c|c|c|c|c|c|c|c|}
\hline & U1 & U2 & U3 & U4 & U5 & U6 & Ca1 & K1 & K2 & Sum & Sum $^{\mathrm{H}}$ & $n \mathrm{H}$ \\
\hline $\mathrm{O} 1$ & 1.61 & & & & & & 0.25 & & & 1.86 & 1.86 & 1 \\
\hline $\mathrm{O} 2$ & 0.61 & 0.86 & & & & 0.56 & & & & 2.03 & 2.03 & 0 \\
\hline $\mathrm{O} 3$ & & 1.62 & & & & & & 0.15 & & 1.77 & 1.77 & \\
\hline $\mathrm{O} 4$ & 0.71 & & & 0.44 & 0.65 & & & & & 1.80 & 1.80 & 1 \\
\hline O5 & & & 0.66 & 0.61 & 0.74 & & & & 0.02 & 2.03 & 2.03 & 0 \\
\hline O6 & & & 0.51 & 0.61 & 0.66 & & & & & 1.79 & 1.79 & 1 \\
\hline $\mathrm{O} 7$ & 0.30 & 0.47 & & & & 0.43 & & & & 1.21 & 2.01 & 0 \\
\hline O8 & 0.68 & 0.69 & & 0.65 & & & & 0.06 & & 2.08 & 2.08 & 0 \\
\hline O9 & & 0.46 & 0.41 & & & 0.40 & & & & 1.27 & 2.07 & 0 \\
\hline O10 & & & & & & & & & 0.11 & 0.11 & 1.71 & 1 \\
\hline O11 & 0.46 & 0.21 & & 0.44 & & & & & & 1.11 & 1.91 & 0 \\
\hline $\mathrm{O} 12$ & 1.68 & & & & & & & 0.15 & 0.12 & 1.95 & 1.95 & 0 \\
\hline O13 & & & & & & 1.65 & 0.02 & & & 1.66 & 1.66 & 2 \\
\hline O14 & & & & & & 1.55 & & 0.08 & 0.16 & 1.79 & 1.79 & 1 \\
\hline O15 & & & 0.69 & & 0.61 & 0.68 & & 0.18 & & 2.16 & 2.16 & 0 \\
\hline O16 & & 1.75 & & & & & 0.17 & & 0.09 & 2.01 & 2.01 & 0 \\
\hline O17 & & & 1.58 & & & & 0.27 & & & 1.84 & 1.84 & 1 \\
\hline $\mathrm{O} 18$ & & & & & 1.60 & & 0.23 & & 0.12 & 1.95 & 1.95 & 0 \\
\hline O19 & & & & 1.55 & & & & & & 1.55 & 1.55 & 2 \\
\hline $\mathrm{O} 20$ & & & & & & & 0.29 & & 0.11 & 0.40 & 2.00 & 0 \\
\hline $\mathrm{O} 21$ & & & & & & & 0.29 & & & 0.29 & 1.89 & 1 \\
\hline $\mathrm{O} 22$ & & & & & & & & & & 0.00 & 1.60 & 2 \\
\hline $\mathrm{O} 23$ & & & 1.65 & & & & & 0.04 & 0.10 & 1.79 & 1.79 & 1 \\
\hline $\mathrm{O} 24$ & & & & 1.48 & & & & 0.08 & 0.18 & 1.75 & 1.75 & 1 \\
\hline $\mathrm{O} 25$ & & & & & 1.44 & & & 0.13 & & 1.57 & 1.57 & 2 \\
\hline $\mathrm{O} 26$ & & & 0.46 & & & 0.57 & & & & 1.04 & 1.84 & 1 \\
\hline $\mathrm{O} 27$ & & & & & & & & 0.10 & & 0.10 & 1.70 & 1 \\
\hline $\mathrm{O} 28$ & & & & & & & 0.31 & & 0.02 & 0.33 & 1.93 & 0 \\
\hline Sum & 6.05 & 6.06 & 5.97 & 5.78 & 5.70 & 5.84 & 1.82 & 0.98 & 1.04 & & & \\
\hline
\end{tabular}

feature, GrIndex. It is a powerful tool, not only for finding the unit cell even from biased data but also for various cell transformations and projections of data.

\section{Acknowledgements}

We thank the two anonymous referees as well as the handling editor Helen Brand for their comments.

\section{Funding information}

This research was supported by the Czech Science Foundation (contract No. GACR 20-11949S) and by the OPVV project Geobarr (contract No. CZ.02.1.01/0.0/0.0/16026/0008459) (grant No. 20-11949S awarded to the Institute of Physics ASCR, v.v.i.).

\section{References}

Brown, I. D. (2002). The Chemical Bond in Inorganic Chemistry: The Bond Valence Model, p. 278. Oxford University Press.

Brown, I. D. (2009). Chem. Rev. 109, 6858-6919.

Cahill, C. L. \& Burns, P. C. (2000). Am. Mineral. 85, 1294-1297.

Casas, I., Bruno, J., Cera, E., Finch, R. J. \& Ewing, R. C. (1997). Geochim. Cosmochim. Acta, 61, 3879-3884.

Cesbron, F., Brown, W. L., Bariand, P. \& Geffroy, J. (1972). Miner. Mag. 38, 781-789. 
Finch, R. J., Cooper, M. A., Hawthorne, F. C. \& Ewing, R. C. (1996). Can. Mineral. 34, 1071-1088.

Finch, R. J. \& Ewing, R. C. (1992). J. Nucl. Mater. 190, 133-156.

Finch, R. J. \& Murakami, T. (1999). Uranium: Mineralogy, Geochemistry and the Environment, edited by P. C. Burns \& R. J. Finch, Reviews in Mineralogy, Vol. 38, pp. 91-179. Washington, DC: Mineralogical Society of America

Finch, R. J., Suksi, J., Rasilainen, K. \& Ewing, R. C. (1996). Mater. Res. Soc. Symp. Proc. 412, 823-830.

Gagné, O. C. \& Hawthorne, F. C. (2015). Acta Cryst. B71, 562-578.

Gorman-Lewis, D., Fein, J. B., Burns, P. C., Szymanowski, J. E. S. \& Converse, J. (2008). J. Chem. Thermodyn. 40, 980-990.

Janeczek, J., Ewing, R. C., Oversby, V. M. \& Werme, L. O. (1996). J. Nucl. Mater. 238, 121-130.

Kirkegaard, M. C., Niedziela, J. L., Miskowiec, A., Shields, A. E. \& Anderson, B. B. (2019). Inorg. Chem. 58, 7310-7323.

Klingensmith, A. L., Deely, K. M., Kinman, W. S., Kelly, V. \& Burns, P. C. (2007). Am. Mineral. 92, 662-669.

Kubatko, K. A., Helean, K., Navrotsky, A. \& Burns, P. C. (2006). Am. Mineral. 91, 658-666.

Lu, K. T., Zhang, Y., Aughterson, R. D. \& Zheng, R. (2020b). Dalton Trans. 49, 15854-15863.

Lu, K. T., Zhang, Y., Wei, T., Čejka, J. \& Zheng, R. (2020a). Dalton Trans. 49, 5832-5841.

Merlet, C. (1994). Mikrochim. Acta, 114-115, 363-376.

Olds, T. A., Plášil, J., Kampf, A. R., Škoda, R., Burns, P. C., Čejka, J., Bourgoin, V. \& Boulliard, J.-C. (2017). Eur. J. Mineral. 29, 129-141.

Olds, T., Plášil, J., Kampf, A. R., Spano, T., Haynes, P., Carlson, S. M., Burns, P. C., Simonetti, A. \& Mills, O. P. (2018). Am. Miner. 103, 143-150.
Petř́íček, V., Dušek, M. \& Palatinus, L. (2014). Z. Kristallogr. 229, 345-352.

Petř́íček, V., Dušek, M. \& Plášil, J. (2016). Z. Kristallogr. 231, 583599.

Plášil, J. (2014). J. Geosci. 59, 99-114.

Plášil, J. (2017). Am. Miner. 102, 1171-1175.

Plášil, J. (2018a). Eur. J. Mineral. 30, 237-251.

Plášil, J. (2018b). J. Geosci. 63, 65-73.

Plášil, J., Kampf, A. R., Olds, T. A., Sejkora, J., Škoda, R., Burns, P. C. \& Čejka, J. (2020). Am. Miner. 105, 561-568.

Plášil, J., Kampf, A. R., Škoda, R. \& Čejka, J. (2018). Acta Cryst. B74, 362-369.

Plášil, J., Petříček, V. \& Škácha, P. (2021). Acta Cryst. B77, 378-383.

Plášil, J., Škoda, R., Čejka, J., Bourgoin, V. \& Boulliard, J.-C. (2016). Eur. J. Mineral. 28, 959-967.

Rigaku (2019). CrysAlis CCD and CrysAlis RED. Oxford Diffraction Ltd, Yarnton, Oxfordshire, UK.

Sheldrick, G. M. (2008). Acta Cryst. A64, 112-122.

Sheldrick, G. M. (2015). Acta Cryst. A71, 3-8.

Wronkiewicz, D. J., Bates, J. K., Wolf, S. F. \& Buck, E. C. (1996). J. Nucl. Mater. 238, 78-95.

Zhang, Y., Aughterson, R., Karatchevtseva, I., Kong, L., Trong Tran, T., Cejka, J., Aharonovich, I. \& Lumpkin, G. R. (2018). New J. Chem. 42, 12267-13184.

Zhang, Y., Aughterson, R., Zhang, Z., Wei, T., Lu, K., Čejka, J. \& Karatchevtseva, I. (2019). Inorg. Chem. 58, 10812-10821.

Zhang, Y., Čejka, J., Lumpkin, G. R., Tran, T. T., Aharonovich, I., Karatchevtseva, I., Price, J. R., Scales, N. \& Lu, K. (2016). New J. Chem. 40, 5357-5363. 